\title{
プレストレスを導入したコンクリート充填円形鋼管の曲げ性状 BENDING BEHAVIOR OF PRE-STRESSED CONCRETE-FILLED STEEL TUBE
}

\author{
䅖山靖司*1, 播繁*2, 河野昭彦*3 \\ Seiji AKIYAMA, Shigeru BAN and Akihiko KAWANO
}

\begin{abstract}
Concrete filled steel tubes (CFT) are widely used in Japan as beam-columns for high-rise building frames because of the high stiffness, strength and deformability in comparison with the other structural members such as shaped-steel sections or vacant steel tubular sections. In this study, a CFT member with a pretensioned steel wire is proposed. In the member, an asphalt thin layer is placed on between steel tube and filled concrete, so that the no bond effect between those is expected. A pre-tensioned steel wire is placed at the center of a CFT section, which introduces the compressive pre-stress into the filled concrete.

The bending test has been done, where the vertical load applies monotonically at the mid span of a simple supported beam composed of a CFT member with steel wire. The test parameters are (1) the diameter-to-thickness ratio $(D / t)$; and $(2)$ the ratio of the pretension force to the axial strength of CFT section. The test revealed that the strength increased when the proper pre-tension force was introduced; the elastic flexural stiffness of the member was adequately evaluated by a simple summation of the concrete stiffness and the steel tube stiffness; and the prediction formulae specified in the present Japanese codes under-estimated or over-estimated by $D / t$ both the yield strength and the maximum strength of the specimen. Therefore, new strength prediction formulae have been proposed based on the test results.
\end{abstract}

Keywords : Concrete-filled steel tubes, Bending Behavior, Stiffness, Strength コンクリート充填鋼管、曲げ性状、剛性、耐力

\section{1. 序論}

コンクリート充填鋼管（以下CFT）は、中空鋼管に比べ剛性、耐 カが高いことから、高層建物の柱材として多く用いられている。 CFTのうち角形CFTは、同一径の円形CFTと比較して曲げ性能等に 優れていることから多く用いられている。一方、円形CFTは鋼管の 拘束により内部コンクリートの強度が上昇する、いわゆる ‘コン ファインド効果' が角形CFTに比較し大きいことが知られている。

筆者らは、円形CFTを梁材やアーチ材のような横架材に用いるこ とを考えた。横架材に用いる場合には自重を減らすことが重要であ るため、曲げモーメントが厳しい部分のみに円形CFT部材を用い、 その他の部分には中空鋼管をフランジ継手で接続して用いることを 考えている。円形CFT部分の充填コンクリートを保持し、また'コ ンファインド効果”を期待して、充填コンクリートにPC鋼線を配 置し、プレストレスを導入することにした。プレストレスを効率的 に充填コンクリートに導入するためには、鋼管とコンクリートの付 着を切るのが理想であるが、実建物に適用できる現実的な方法とし て鋼管内面にアスファルトを塗布し付着を切ることは出来ないまで
も付着の低減を図ることにした。

円形CFTにプレストレスを導入した部材の研究は、土木分野にお いて数件行われている。前川ら1)は、落石防止相の支柱を対象に、 ボンドまたはアンボンドの円形鋼管 $(D / t=37)$ にコンクリートを充填 し、ボンドまたはアンボンドのPC鋼棒2本または4本を配置した梁 材の曲げ実験を行った。その結果、ボンド型、アンボンド型とも配 置されたPC鋼棒が高強度の曲げ引張筋として働くことにより梁材 の耐力と変形性能が飛躍的に向上するが、そのPC鋼棒にプレスト レスを入れることによる耐力向上はなく、勒性を低下させるとして いる。また、平面保持を仮定し、材料の応力ーひずみ関倸に材料試 験結果を用いた曲げ解析方法により $10 \%$ 程度の誤差で最大耐力を評 価できるとしている。

小林、大久保ら 2) 6) は、鋼管径厚比 $(D / t=30 、 40 、 53)$ とプレス トレス量をパラメータとし、ボンド型PC鋼線を曲げ引張側に配し たプレストレスト鋼管コンクリート梁材の曲げ実験を行った。実験 の結果、最大耐力はPC鋼線の破断により決まり、鋼管厚が厚いほ ど大きいが、プレストレス量にはほとんど影響されないとしてい

*1 鹿島技術研究所 上席研究員 · 工修

*2 (有)播設計室 代表取締役 (元 鹿島構造設副部)

*3'九州大学大学院人間環境学研究院 教授.$工$ 博
Supervisory Research Engineer, Kajima Technical Research Institute, M. Eng. Representative Director, VAN STRUCTURAL DESIGN

Prof., Faculty of Human-Environment Studies, Kyushu University, Dr. Eng. 
る。最大耐力は周方向応力の増大を考慮した拘束コンクリートの構 成則を用いた解析により $D / t=53$ のものは精度良く評価できるが、 $D / t$ =30のものは解析値が低くなると報告している。

保坂らすは、鋼管主桁橋梁の曲げモーメントが大きい部分を対象 にPC鋼線を曲げ引張側に配したボンド型プレストレスト鋼管コン クリート梁材 $(D / t=76)$ のC 鋼線の有無及びプレストレスの有無をパ ラメータとした曲げ実験を行い、最大耐力はPC鋼線を配置するこ とにより増加するが、プレストレスの導入による影響は期待できな いとしている。プレストレスを導入したものはPC鋼線の破断によ り最大耐力が決まっている。また、鋼管と PC鋼線を鉄筋に置換 し、鉄筋コンクリート部材として曲げ耐力を評価すると、計算值は 実験值を $30 \%$ 程度低く評価することになると報告している。

以上の文献で得られた知見は、円形CFTにPC鋼材を配置するこ とにより曲げ耐力が上昇し、勒性も向上するが、プレストレスは耐 力増加には影響なく、プレストレスが大きいと勒性は低下するとい うものである。ただし、これらはいずれもPC鋼材を曲げ引張側に （一部は圧縮側にも）配しているため、曲げ耐力向上に効果的であ る反面、 $\mathrm{PC}$ 鋼材破断時には急激に荷重が低下する。また、曲げ耐 力の評価は断面の平面保持を仮定し、断面を分割して計算機を用い て数値積分する方法を用いているが、実際の設計に用いるには煩雑 である。

本研究では、建築構造用の部材、つまり土木構造用部材に比較す れば小断面を対象としていることから、PC鋼材は断面の中央に1本 だけ配する場合を考えた。このため引張筋としての直接的な曲げ耐 力向上は見込めないが、充填コンクリート部分が曲げの初期から全

\begin{tabular}{c|c|c|c|c}
\multicolumn{5}{c}{ 表 1 実験パラメータ } \\
\hline$D_{D / t}^{N_{0} / N_{u}}$ & 0 & 0.3 & 0.5 & 0.7 \\
\hline 45 & 0 & 0 & $\bigcirc$ & $\bigcirc$ \\
\hline 72 & & $\bigcirc$ & $\bigcirc$ & $\bigcirc$ \\
\hline 103 & & & 0 & \\
\hline
\end{tabular}

断面有効になること、及び鋼管の拘束によりコンクリートの強度が 上昇することによって剛性と耐力の向上が期待できる。本稿では、 そのような円形CFT材の基本的な曲げ性状を把握するために載荷実 験を行ったのでその結果を報告するとともに、曲げ剛性推定式及び 曲げ耐力推定式を提案する。

\section{2. 実験計画}

本実験はコンクリート部分にプレストレスを導入したコンクリー 卜充填銅管の曲げ性状を把握するための基礎実験で、鋼管の径厚比 $(D / t)$ 、及びプレストレス (PS) 比 $\left(=N_{0} / N_{u} 、 N_{0}\right.$ は、PS導入量、 $N_{u}$ は、鋼管とコンクリートの累加軸耐力）をパラメータとし、これら がコンクリート充填鋼管の曲げ性状に及ぼす影響を定量的に把握す ることを目的とした。径厚比 $(D / t)$ は 45、72、103の3水準、PS比は $0 、 0.3 、 0.5 、 0.7 の 4$ 水準とした。実験パラメータの一覧を表 1 に、試験体の形状・寸法等を図 Iに、試験体の諸元を表 2 に示す。 鋼管の材質はSTK400またはその相当品とした。鋼管には冷間成型 過程で生じる残留応力を除去し、降伏棚が明確に現れる材料にする ため熱処理を施した。熱処理は $620^{\circ} \mathrm{C} の$ 炉中に 20 分入れ、炉冷とい う条件で行った。PC鋼材にはアンボンドPC鋼より線 $7 \times \phi 11.1$ （SWPR7B）を用いた。7× 611.1 (SWPR7B) の機械的性質はJIS G 3536 に規定されており、0.2\%永久伸びに対する荷重は $118 \mathrm{kN}$ 以 上、引張荷重は $138 \mathrm{kN}$ 以上、伸びは $3.5 \%$ 以上である。コンクリー トは早強セメントを用い、配合強度は、鋼管の拘束によるコンク リート強度の上梨が明確になるように19N/ $\mathrm{mm}^{2}$ とした。表 3 に使

表 3 鋼材強度試験結果*1

\begin{tabular}{c|l|r|r|r}
\hline 種類 & \multicolumn{1}{|c|}{ 材種 } & $\begin{array}{c}\text { 降伏応力度 } \\
{ }^{s} \sigma_{y} \\
\mathrm{~N} / \mathrm{mm}^{2}\end{array}$ & $\begin{array}{c}\text { 引張強さ } \\
{ }_{s} \sigma_{u} \\
\mathrm{~N} / \mathrm{mm}^{2}\end{array}$ & \multicolumn{1}{c}{$\%$} \\
\hline$\phi-165.2 \times 3.7$ & STK400 & 371 & 497 & 37.0 \\
\hline$\phi-165.2 \times 2.3$ & STK400相当 & 393 & 465 & 38.6 \\
\hline$\phi-165.2 \times 1.6$ & STK400相当 & 319 & 380 & 41.4 \\
\hline${ }^{\star} 1$ JIS $12 \mathrm{~B}$ 号 3本の平均值 & \multicolumn{3}{|c}{}
\end{tabular}

表 2 試験体緒元および主な実験結果一覧

\begin{tabular}{|c|c|c|c|c|c|c|c|c|c|c|c|c|c|c|}
\hline \multirow[b]{3}{*}{ 名称 } & \multicolumn{5}{|c|}{ 試験体緒元 } & \multicolumn{9}{|c|}{ 主な実験結果 } \\
\hline & \multirow{2}{*}{$\begin{array}{c}\text { 管径 } \\
\text { (実測) } \\
D \\
\text { mm }\end{array}$} & \multirow{2}{*}{$\begin{array}{c}\text { 管厚 } \\
\text { (実測) } \\
t \\
\mathrm{~mm} \\
\end{array}$} & \multirow[b]{2}{*}{$\begin{array}{c}\text { 径厚比 } \\
D / t\end{array}$} & \multirow[b]{2}{*}{$\mid \begin{array}{c}\text { 軸耐力 } \\
N_{u} \\
\mathrm{kN}\end{array}$} & \multirow[b]{2}{*}{$\begin{array}{c}\text { PSEL } \\
N_{0} / N_{u}\end{array}$} & \multicolumn{3}{|c|}{ 初期剛性 $K$} & \multicolumn{3}{|c|}{ 降伏荷重 $M_{y}$} & \multicolumn{3}{|c|}{ 終局荷重 $M_{u}$} \\
\hline & & & & & & $\mathrm{kN}^{*} \mathrm{~m}$ & $\begin{array}{l}\text { 計算值 } \\
\mathrm{kN}^{*} \mathrm{~m}\end{array}$ & $\begin{array}{l}\text { 実験値 } \\
\text { 計算值 }\end{array}$ & $\begin{array}{l}\text { 実験值 } \\
\mathrm{kN}^{*} \mathrm{~m}\end{array}$ & $\begin{array}{l}\text { 計算值 } \\
\mathrm{kN}^{*} \mathrm{~m}\end{array}$ & $\begin{array}{l}\text { 実験值 } \\
\text { 計算值 }\end{array}$ & $\begin{array}{l}\text { 実験值 } \\
\mathrm{kN}^{*} \mathrm{~m}\end{array}$ & $\begin{array}{l}\text { 計算值 } \\
\mathrm{kN}^{*} \mathrm{~m}\end{array}$ & $\begin{array}{l}\text { 実験值 } \\
\text { 計算值 }\end{array}$ \\
\hline $45-0$ & 165.2 & 3.2 & 45 & 1005 & 0.0 & 5428 & 7067 & 0.77 & 28.2 & 24.0 & 1.17 & 39.3 & 37.9 & 1.04 \\
\hline $45-0.3$ & 165.2 & 3.2 & 45 & 1005 & 0.3 & 6404 & 7067 & 0.91 & 30.8 & 25.8 & 1.19 & 42.5 & 41.2 & 1.03 \\
\hline $45-0.5$ & 165.2 & 3.2 & 45 & 1005 & 0.5 & 7006 & 7067 & 0.99 & 24.8 & 19.9 & 1.25 & 38.3 & 38.2 & 1.00 \\
\hline $45-0.7$ & 165.2 & 3.2 & 45 & 1005 & 0.7 & 6041 & 7067 & 0.85 & 18.8 & 12.1 & 1.55 & 31.1 & 31.3 & 0.99 \\
\hline $72-0.3$ & 165.3 & 2.0 & 72 & 816 & 0.3 & 4975 & 5655 & 0.88 & 20.5 & 19.6 & 1.05 & 26.3 & 30.3 & 0.87 \\
\hline $72-0.5$ & 165.3 & 2.0 & 72 & 816 & 0.5 & 5724 & 5655 & 1.01 & 17.5 & 16.6 & 1.05 & 21.9 & 28.8 & 0.76 \\
\hline $72-0.7$ & 165.3 & 2.0 & 72 & 816 & 0.7 & 5053 & 5655 & 0.89 & 11.8 & 10.1 & 1.17 & 16.5 & 23.6 & 0.70 \\
\hline $103-0.5$ & 165.6 & 1.7 & 103 & 696 & 0.5 & 4972 & 5323 & 0.93 & 11.7 & 12.6 & 0.93 & 17.3 & 22.2 & 0.78 \\
\hline
\end{tabular}

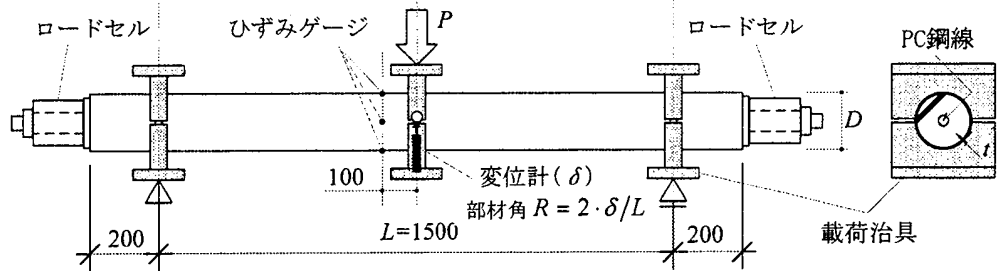

図 1 試験体の形状、寸法
表 4 コンクリート強度試験結果

\begin{tabular}{c|c|c}
\hline 種類 & $\begin{array}{c}\text { 圧縮強度 } \\
{ }_{c} \sigma_{B}\end{array}$ & $\begin{array}{c}\text { ヤング係数 } \\
{ }_{c} E\end{array}$ \\
\hline $\mathrm{N} / \mathrm{mm}^{2}$ & $\mathrm{~N} / \mathrm{mm}^{2}$ \\
\hline $\mathrm{Fc} 19$ & 20.2 & 21300 \\
\hline
\end{tabular}


用鋼材の強度試験結果、表 4 にコンクリートの強度試験結果を示 す。また、コンクリートと鋼管の付着を低隇するため、鋼管の内側 にスプレー缶入りアスファルト乳剂を吹き付けた。吹き付けは、ス プレーを開放した状態で回転させながら鋼管内を低速で往復させる ことにより行った。塗り厚は平均で $200 \mu \mathrm{m}$ とし、溶冎が蒸発した後

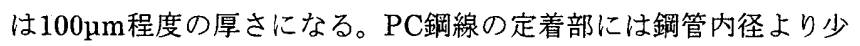
し小さい円盤の載荷板を設置することにより、コンクリートのみに 圧縮力がかかるようにした。プレストレスの導入時期は、曲げモー メント載荷の直前とした。

加力は試験体の両端を単純支持し、3 点曲げの一方向載荷で行っ た。支点及び載荷点は円筒形の凹形载荷治具を介することにより鋼 管に局部的な力がかからないようにした。加力プログラムは、加力 点の曲げモーメント $M$ が $1 / 2 \times M_{p}$ （ $M_{p}$ は中空鋼管の全塑性曲げモー メント計算値）と $M_{p}$ のときに一旦除荷し、最終的に部材角 $R=150 \times$ $10^{-3} \mathrm{rad}$ ま゙加力した。載荷点の鉛直変位 $(\delta)$ と載荷点から水平に $100 \mathrm{~mm}$ 離れた位置の鋼管の上面、側面、下面の歪を 3 軸ゲージで 測定した。PC鋼線の定着部にはセンターホールのロードセルを挟 み、張力を測定した。

\section{3. 実験結果}

剛性と降伏荷重及び終局荷重の実験結果を表2に示す。初期剛性 （K）の計算值は、（1）式に示すコンクリートを全断面有効と仮定し た鋼管とコンクリートの弾性剛性の累加とした。初期剛性の実験值

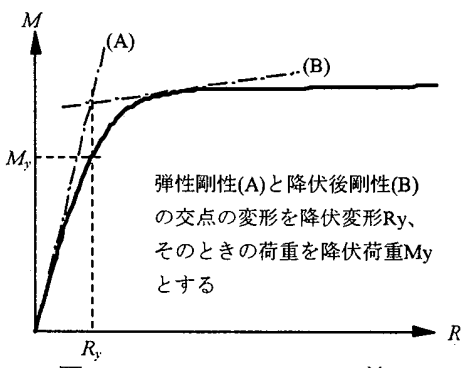

図 2 General Yield Point法

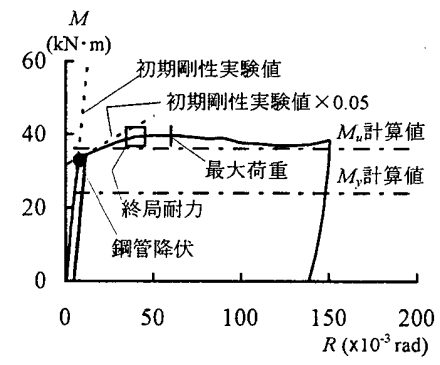

(a) $45-0$

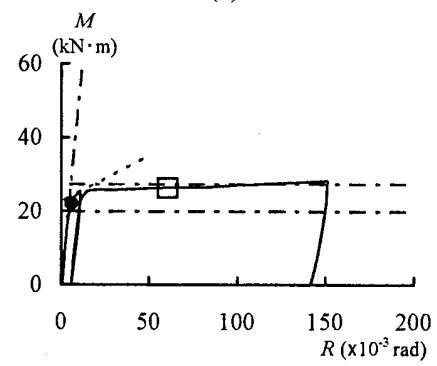

(e) $72-0.3$

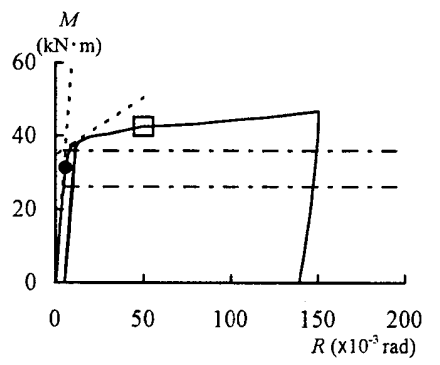

(b) $45-0.3$

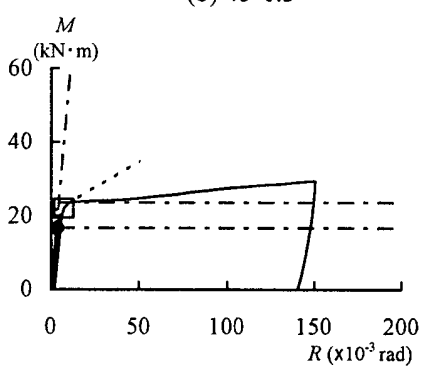

(f) $72-0.5$

図 3 荷重一変形関倸

線剛性とした。

$$
K=\frac{M}{R}=\frac{12 \pi \cdot{ }_{c} E \cdot r^{4}}{L} \cdot\left(\frac{1}{8}+n \cdot \frac{t \cdot r^{3}}{2 \cdot r^{4}}\right)
$$

ここで、

$$
\begin{aligned}
& n=\frac{{ }^{E}}{{ }_{c} E} \quad: \text { ヤング倸数比 } \\
& { }_{s} E \text { : 鋼のヤング係数（=205800N } / \mathrm{mm}^{2} \text { とする） } \\
& { }_{c} E \quad: \text { コンクリートのヤング係数 } \\
& t \text { : 鋼管の厚さ } \\
& { }_{s} r \quad: \text { 鋼管の管厚中心の半径 } \\
& r \quad: \text { ヨンクリート断面の半径 }
\end{aligned}
$$

降伏曲げモーメント $\left(M_{y}\right)$ の計算値と終局曲げモーメント $\left(M_{u}\right)$ の計算值はそれぞれ文献8）の短期許容応力度に基づく計算值と終局

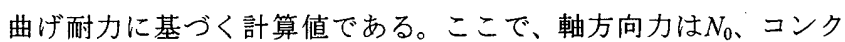
リート強度は 材料試験による $c \sigma_{B}$ を用いた。降伏耐力の実験值は、 図 2 に示すGeneral Yield Point法によって求めた。終局耐力の実験 值は、鋼材の歪硬化しない範囲の全塑性状態を想定し、引張縁の材 軸方向の歪が1\%に達した点と定義した。

\section{荷重一変形関倸}

$M-R$ 関保を図 3 に示す。図 3 中の「鋼管降伏」は、鋼管に貼付 した 3 軸ゲージの測定値による相当歪が鋼管の降伏歪 $\varepsilon_{y}$ に達した

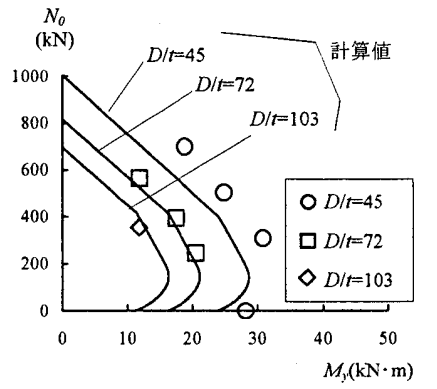

(a) 降伏耐力

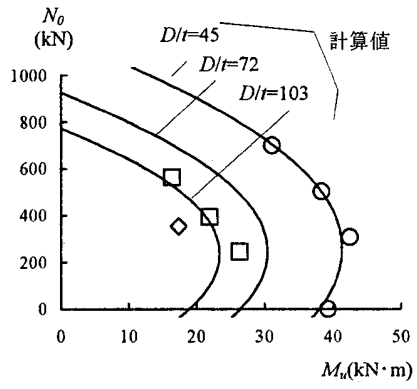

(b) 終局耐力

図 4 プレストレス量と降伏耐力、終局耐力の関係

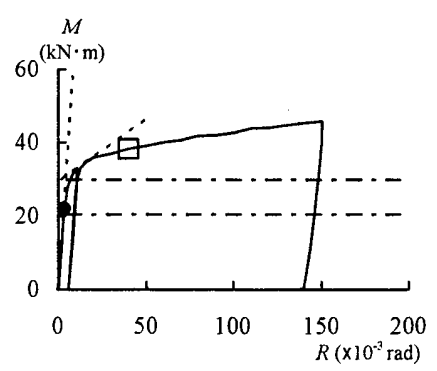

(c) $45-0.5$

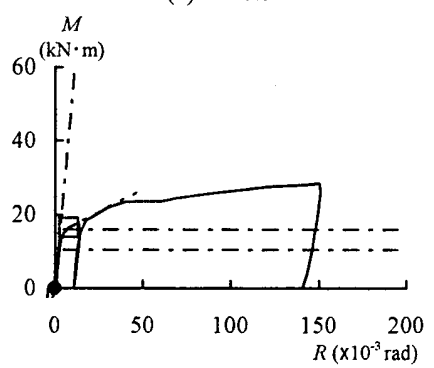

(g) $72-0.7$

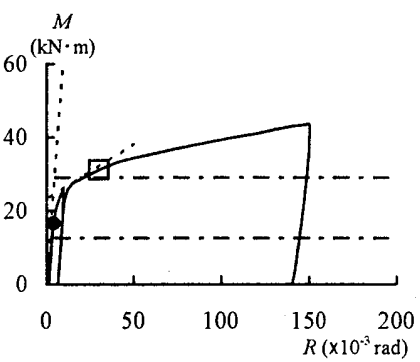

(d) $45-0.7$

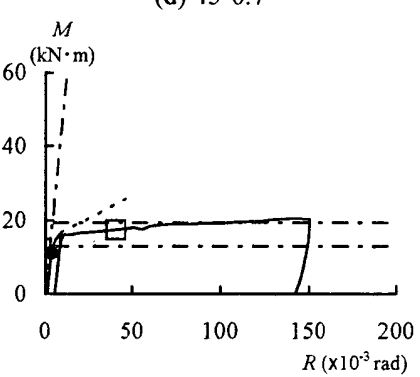

(h) $103-0.5$ 
点である。図 3 はプレストレスを導入した場合（試験体45-0以外の

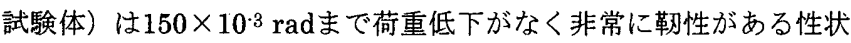
を示している。試験体72-0.7は、プレストレスを導入した時点で銿管 が降伏したが、その後も抵抗力は増大し続け、安定した性状を示し た。これは、鋼管は降伏後も安定したコンクリートへの拘束力、鋼 管自身の曲げモーメント抵抗力を保持していることを示している。

プレストレスを導入していない試験体 $45-0$ は $R=60.29 \times 10^{3}$ で最大 荷重に達した後徐々に荷重が低下し、変形が大きくなると（R=140 $\left.\times 10^{3}\right)$ 再び荷重がやや上昇に転じている。一旦荷重が低下するの は、コンクリートの軸方向拘束が小さいためで、そのためにその後 内部コンクリートが軸方向に膨張しPC鋼線により拘束されるように なるためであると考えられる。

なお、すべての試験体は、鋼管が降伏した後、加力点付近の圧縮 側に局部座屈が生じたが、荷重低下は見られなかった。 初期剛性

表 2 によるとプレストレスを導入しない試験体の弾性剛性は計 算值の0.8倍以下であった。プレストレス比が 0.5 のものは 0.93 倍以 上、プレストレス比が 0.3 及び 0.7 ののは $0.85 \sim 0.91$ 倍であった。 これは、プレストレス量が小さすぎても大きすぎてもわずかな曲げ を受けただけでコンクリートが部分的に引張ひずみになったり、圧 壊ひずみに近づいたりして剛性が低下することを示している。

降伏耐力

図 4 (a)に、導入プレストレス量と降伏耐力の関倸を示す。この図 によれば実験による降伏耐力は 径厚比が小さいほどMy゙大きく、同 じ径厚比 $D / t=45$ で比較すると、 $N_{0} / N_{u}=0 、 0.3 、 0.5 、 0.7$ 中では、 $N_{0} / N_{u}=0.3$ のときに $M_{y}$ が最大となっている。図中の計算値は文献8）に よる短期許容耐力である。 $D / t=72 、 D / t=103$ の計算值は実験值によ く一致しているが、 $D / t=45$ の計算值は、実験值よりかなり小さい。 終局耐力

図 4 (b)に、導入プレストレス量と終局耐力の関係を示す。図 4 (b) によれば降伏耐力と同様、終局耐力も径厚比が小さいほどMy く、同じ径厚比 $D / t=45$ で比較すると、 $N_{0} / N_{u}=0 、 0.3 、 0.5 、 0.7$ の中で は、降伏耐力と同様、 $N_{0} / N_{u}=0.3$ のきに $M_{y}$ が最大となっている。こ れは、 $N_{0} / N_{u}=0.3$ 程度のプレストレスを導入すればコンクリートの

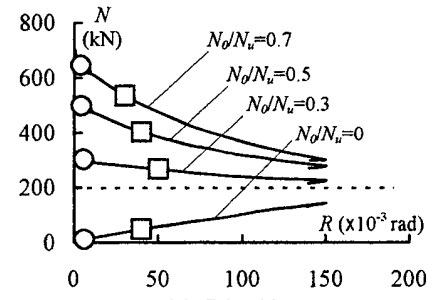

(a) $D / t=45$

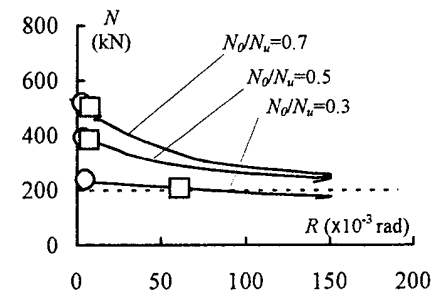

(b) $D / t=72$

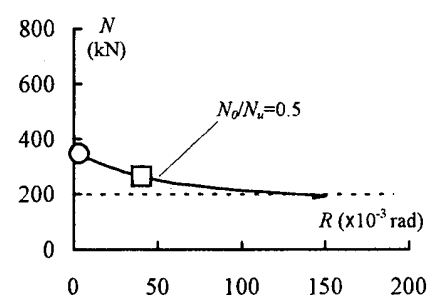

(c) $D / t=103$
図 5 PC鋼線の張力一変形関係
耐力への奇与と鋼管の降伏耐力の低下の関係で最大の耐力が得られ ることを示している。図中計算值は文献8）による終局曲げ耐力計算 值である。 $D / t=450$ ものは実験終局耐力によく一致しているが、 $D /$ $t=72 、 D / t=103$ にいては、計算值は実験値を過大評価している。

\section{PC鋼線の張力の変化}

図 5 にPC鋼線の張力と変形の関係を示す。PC鋼線の張力は変形 の増大とともに変化する。 $N_{0} / N_{u}=0.3$ 以上のものは、変形の増大と ともに張力が減少し、 $N_{0} / N_{u}=0$ のものは変形の増大とともに張力が 生じ最終的に初期導入張力や管厚比に関係なく200kN付近に漸近す る。したがって、仮にさらに加力を続けていたとしても、PC鋼線 の破断及びそれによる急激な荷重の低下はないと推定される。

\section{4. 㓮性、耐力推定式の提案}

前章で、初期剛性の実験値と鋼管とコンクリートの累加剛性計算 值を比較した。その結果、プレストレス比が 0.5 程度のものは累加 剛性計算值に近いが、それよりプレストレス比が大きくても小さく ても剛性は小さくなることが確認された。これは、プレストレスが 小さいときは初期剛性算定時にコンクリート断面の一部が引張ひず みになり、逆にプレストレスが大きすぎるとコンクリート断面の一 部がコンクリート強度に達するため、同一の剛性評価法では評価で きないためだと考えられる。そのことを考慮した初期剛性計算値を 提案する。

また、降伏耐力と終局耐力の実験值と文献8）によるそれぞれの計 算值を比較した。文献8）の計算式は鋼管のコンファインド効果によ る充填コンクリート強度の上昇、鋼管に周方向引張応力が生じるこ とによる引張降伏応力度の上昇、及び圧縮降伏応力度の低下を考慮 しているが、その值が固定されている。ここでは、鋼管とコンク リートのひずみ差を考慮した降伏耐力及び径厚比とコンファインド 効果の関倸を考慮した終局耐力の予測法を提案する。 初期剛性

断面が重心ひずみ $\varepsilon_{0}$ と曲率 $\phi$ 状態にあるときの軸力 $N$ と曲げモー メントMを断面の軸方向応力分布を積分することにより求め、軸力 がプレストレス量、曲げモーメントが初期剛性算定時曲げモーメン ト (以下 $M_{k}$ ) のときの割線剛性を初期剛性とする。 $M_{k}$ は、実験值の 定義と同様に $1 / 4_{s} M_{y}$ とする。 $M_{k}$ 時の断面状態等に以下の仮定を設け

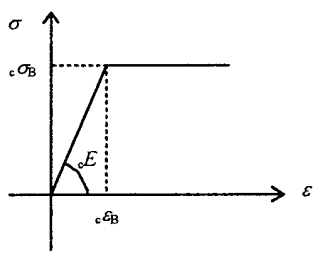

図 6 コンクリートの忘カーひずみ関係

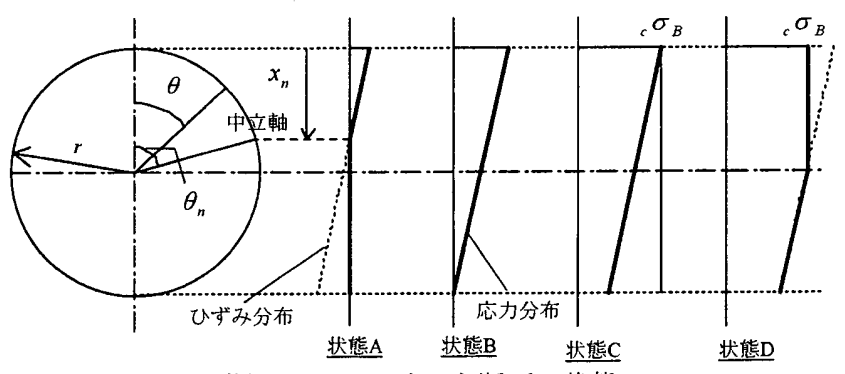

図 7 コンクリート断面の状態 
る。

1)銅管とコンクリートの平面保持が成立する。

2）銅管はコンクリートに対し拘束効果を発揮しないが、コンク

リートが強度に達した後、圧壊を防ぐ役割を果たす。コンク

リートの応カーひずみ関係は図 6 に示すようにbi-linearとす る。

3)鋼管は弾性状態である。

コンクリート断面の忘力状態はPS量によって弾性状態であった り、断面の一部が引張になったり、コンクリート強度に達したりし

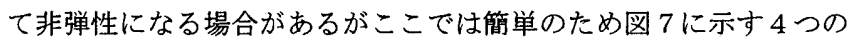
状態の初期剛性を求め、それらの間は直線補間で求めることとす る。4つの状態とは、コンクリート断面が下記のようになる状態で ある。

状態A : コンクリート断面の一部が引張ひずみになり、鋼管部分 とコンクリート部分の軸力の和が 0 になる状態

状態 $\mathrm{B}$ : 全断面が弾性状態であり、コンクリート断面の引張縁の 応力がちょうど0である状態

状態C : 全断面が弾性状態であり、コンクリート断面の圧縮縁の 応力がちょうどコンクリート強度に達している状態

状態D : コンクリート断面の半分がコンクリート強度に達してい る状態

状態Aでは、 $N=0$ であるからは下式が成り立つ。（以降、特に記 述がない場合、応力、歪の正負は、圧縮を正とする。）

$\frac{\sin ^{3} \theta_{n}}{3}-\cos \theta_{n} \cdot\left(\frac{\theta_{n}}{2}-\frac{\sin 2 \theta_{n}}{4}+\pi \cdot n \cdot \frac{t \cdot s}{r^{2}}\right)=0$

ここで、

$\theta_{n} \quad$ : 中立軸位置を表わす角度 (図 7 参照)

また、M/ ゆは下式に (2) 式が成り立つ $\theta_{n}$ を代入することにより求めら れる。

$$
\begin{aligned}
\frac{M}{\phi}= & 2 \cdot{ }_{c} E \cdot r^{4} \\
& \times\left\{\frac{1}{8} \cdot\left(\theta_{n}-\frac{\sin 4 \theta_{n}}{4}\right)-\cos \theta_{n} \cdot \frac{\sin ^{3} \theta_{n}}{3}+\pi \cdot n \cdot \frac{t \cdot s r^{3}}{2 \cdot r^{4}}\right\}
\end{aligned}
$$

ここで、

$$
\phi \quad: \text { 曲率 }
$$

実験結果の初期剛性はMIRで得られているため、材の全長にわたっ て同一の剛性であると仮定し、MI/を下式によりM/Rに換算する。 $\frac{M}{R}=\frac{M}{\phi} \cdot \frac{6}{L}$

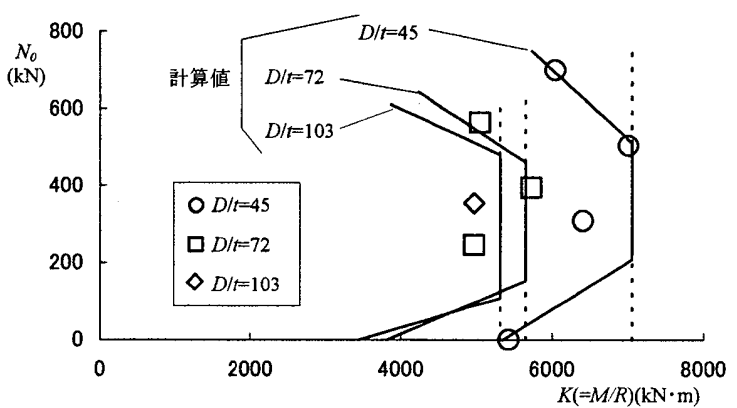

図 8 プレストレス量と初期剛性の関倸（提案式との比較）
$M / \phi$ か $M / R$ への換算は以下も同様である。

状態Bと状態Cでは、断面は弾性状態であるので初期剛性は (1)式に より計算する。

状態 $\mathrm{B}$ と状態Cの軸力は、下式により計算される。

$$
\frac{N}{\pi \cdot r^{2} \cdot{ }_{c} E}=\varepsilon_{0} \cdot\left(1+2 \cdot n \cdot \frac{t \cdot{ }_{s} r}{r^{2}}\right)
$$

ここで、

$$
\varepsilon_{0} \quad: \text { 断面重心のひずみ }
$$

状態BのNは、

$$
\varepsilon_{0}=r \cdot \phi
$$

を(5)式に代入し、状態CのNは、

$$
\varepsilon_{0}={ }_{c} \varepsilon_{B}-r \cdot \phi
$$

を(5)式に代入することにより得られる。

状態Dの $M 、 N$ は下式で表わされる。

$$
\begin{aligned}
& \frac{N}{2 \cdot{ }_{c} E \cdot r^{2}}={ }_{c} \varepsilon_{B} \cdot\left(\frac{\pi}{2}+\pi \cdot n \cdot \frac{t \cdot{ }_{s} r}{r^{2}}\right)+\frac{1}{3} \cdot \phi \cdot r \\
& \frac{M}{2 \cdot{ }_{c} E \cdot r^{4} \cdot \phi}=\frac{\pi}{16}+\pi \cdot n \cdot \frac{t \cdot{ }^{2} r^{3}}{2 \cdot r^{4}}
\end{aligned}
$$

(9) 式で $M=M_{k}$ となる $\phi$ を求め、その $\phi$ を(8) 式に代入すると状態 $\mathrm{D} の N$ が得られる。

(2) (9)式で求められた 4 つの状態での $K(=M / R)$ と $N$ を直線で結ぶ と、 $K-N$ の相関曲線となる。計算結果を実験值と重初て図 8 に示 す。破線は (1) 式による計算值である。この図によると、 $N_{0}=0$ と $N_{0}=0.7 N_{u}$ では評価式は実験值に近づいているが、 $N_{0}=0.3 N_{u}$ では改善 されていない。このような結果になる可能性の一つとして、乾燥ま たは硬化収縮によりコンクリートには初期引張ひずみが生じてお り、 $N_{0}=0.3 N_{u}$ 程度のプレストレス量、 $M_{k}$ 程度の曲げでは、鋼管とコ ンクリートの付着により、まだコンクリートの全断面が圧縮にはな らないことが考えられる。
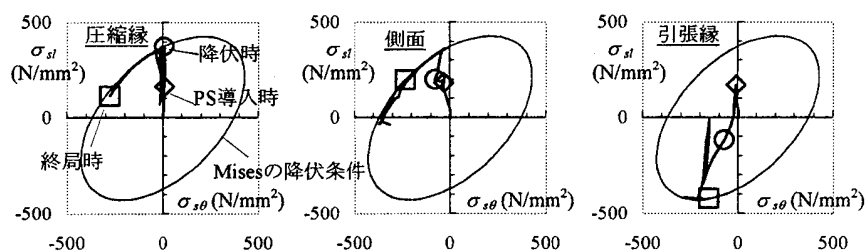

(a) $45-0.5$
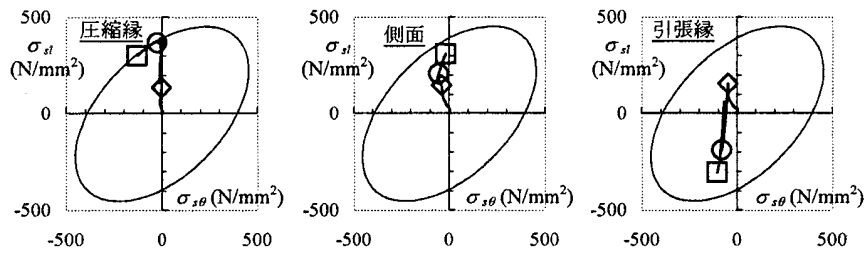

(b) $72-0.5$
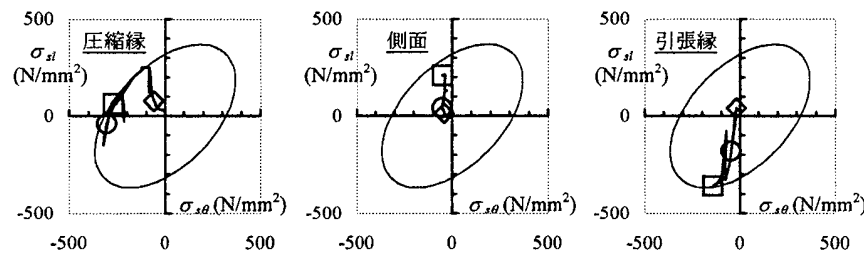

(c) $103-0.5$

(圧縮を正とする)

図 9 鋼管の軸方向応力一周方向応力関倸 


\section{鋼管の忘力状態の検討}

まず、降伏耐力や終局耐力を推定する根拠となるデータを得るた めに、鋼管に貼付した歪ゲージの測定結果からMisesの降伏条件と Reussの方程式に基づく方法9)により鋼管の弹塑性応力を求め、そ の推移を調べた。代表的な 3 体についてその結果を図 9 に示す。こ の図から以下のことが言える。

1)プレストレスを導入すると、103-0.5の側面を除き、軸方向に圧縮 忘力が生じている。これは、付着を減少させる処理をしていると はいえ、コンクリートに導入された圧縮力が鋼管とコンクリート の摩擦により鋼管に流れているためであると思われる。

2)プレストレスを導入から降伏に至るまで、103・0.5の圧縮縁を除き 周方向応力はほとんど生じない。

3）曲げ圧縮縁では、Misesの降伏楕円に達した後、終局時までに応 力状態は降伏楕円上を周方向引張岕力が増える方向に移動する。

4）引張縁では、72-0.5を除き、終局時にMisesの降伏棈円上で軸方 向応力度が最大になる点に達する。

5)側面では、45-0.5を除き、終局時まで周方向応力は生じない。

以上、代表的な 3 体についてのみでも完全に一致した傾向が述べ られるわけではないが、他の5体についても上記と同様に言えるも の言えないものいろいろであった。このことを考虑し、降伏耐力ゃ 終局耐力を推定するために鋼管の応力状態の推移の仮定に関しては 実験結果とのそれほどの厳密な一致は求めないこととした。

降伏耐力推定式

降伏曲げモーメント $M_{y}$ 、降伏軸力 $N_{y}$ は下式のように銅管とコンク リートの耐力の和とする。

$$
\begin{aligned}
& M_{y}={ }_{s} M_{y}+{ }_{c} M_{y} \\
& N_{y}={ }_{s} N_{y}+{ }_{c} N_{y}
\end{aligned}
$$

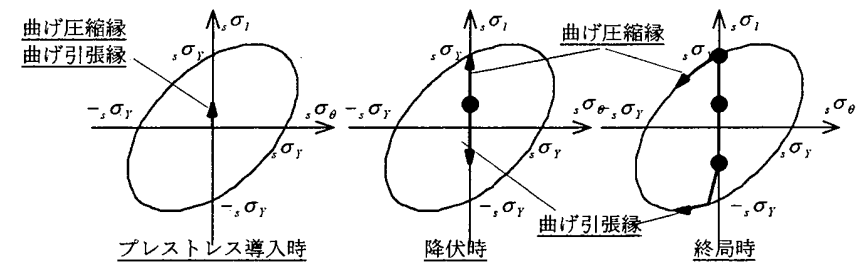

(a)鋼管の応力状態

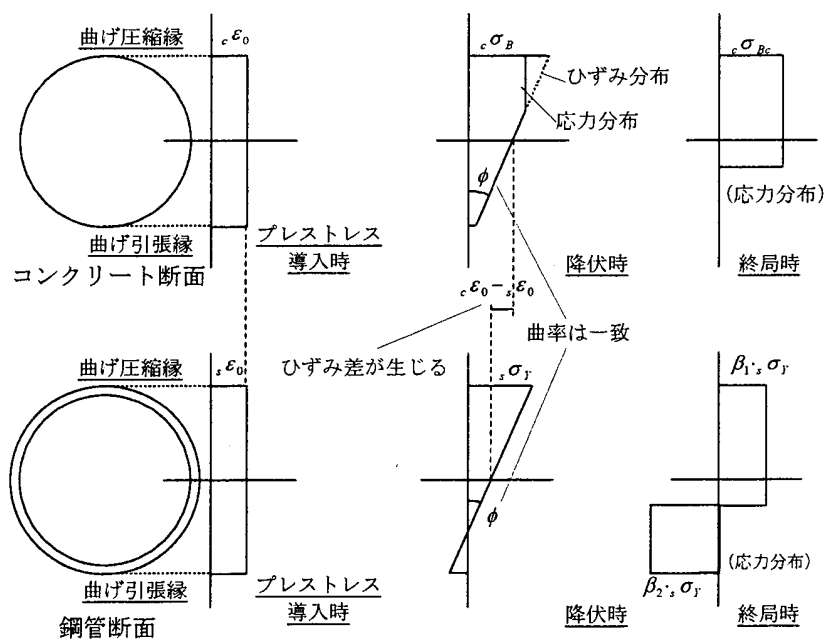

(b)断面の応力、ひずみ分布

図 10 鋼管の応力状態、断面の応力、ひずみ分布の仮定
ここで、

${ }_{s} M_{y} \quad ：$ 鋼管の降伏曲げモーメント

${ }_{c} M_{y} \quad:$ コンクリートの降伏曲げモーメント

${ }_{s} N_{y}:$ : 鍓管の降伏軸力

${ }^{2} N_{y} \quad:$ コンクリートの降伏軸力

${ }_{s} M_{y} 、{ }_{c} M_{y} 、{ }_{s} N_{y} 、{ }_{c} N_{y}$ を求めるために、プレストレス導入から降伏に 至るまでの挙動に以下の仮定を設ける。

1)鋼管、コンクリートはそれぞれ独立に平面保持が成立する。鋼管 とコンクリートの間にはある軸歪差が生じて、鋼管ーコンク リート間の平面保持は成立しないが、曲率は一致する。（図 1 0 (b)参照)

2)降伏時の鋼管とコンクリートの軸ひずみは、もしともに弾性状態 にあるとした場合にポアソン比分の横ひずみが等しくなる量と する。

3)鋼管はコンクリートに対し拘束効果を発揮しないが、コンクリー トが圧縮強度に達した後、压壊を防ぐ役割を果たす。すなわ ち、コンクリートの応カー歪関係は、図 6 に示すように完全弾 塑性で表わされるものとする。

鋼管部分の ${ }_{s} M_{y}-{ }_{s} N_{y}$ 相関曲線は中空の鋼管と同様、下式で表わさ れる。

$$
{ }_{s} M_{y}={ }_{s} M_{y 0} \cdot\left(1-\frac{\left|s N_{y}\right|}{{ }_{s} N_{y 0}}\right)
$$

ここで、

${ }_{s} M_{y 0} \quad$ : 軸力がないときの銅管の降伏曲げモーメント

${ }_{s} N_{y 0} \quad:$ 曲げモーメントがないときの鋼管の降伏軸力

${ }_{s} M_{y}-{ }_{s} N_{y}$ 相関曲線上での断面重心の鋼管のひずみ及び曲率は下式 で表わされる。

$$
\begin{aligned}
& { }_{s} \varepsilon_{0}=\frac{{ }_{s} N_{y}}{{ }_{s} E \cdot{ }_{s} A} \\
& \phi=\frac{{ }_{s} M y_{y}}{{ }_{s} E \cdot{ }_{s} I}
\end{aligned}
$$

ここで、

${ }_{s} \varepsilon_{0} \quad:$ 断面重心の銿管のひずみ

${ }_{s} A,{ }_{s} I$ : それぞれ鋼管の断面積および断面2次モーメント 仮定2)により、断面重心の位置のひずみ差は下式で表わされる。

$$
{ }_{c} \varepsilon_{0}-{ }_{s} \varepsilon_{0}={ }_{s} \varepsilon_{0} \cdot\left(\frac{{ }_{s} v}{{ }_{c} v}-1\right)
$$

$$
\text { ここで、 }
$$

${ }_{c} \varepsilon_{0} \quad:$ 断面重心のコンクリートのひずみ

${ }_{c} v{ }_{s} v \quad:$ それぞれコンクリートおよび鋼管のポアソン比 コンクリートの軸力と曲げモーメントは、図 11 に示すCase1〜 Case6の忘力分布ごとに次のように求められる。なお、ここでは、 便宜上コンクリートが圧縮強度に達する位置を圧壊軸と呼ぶ。

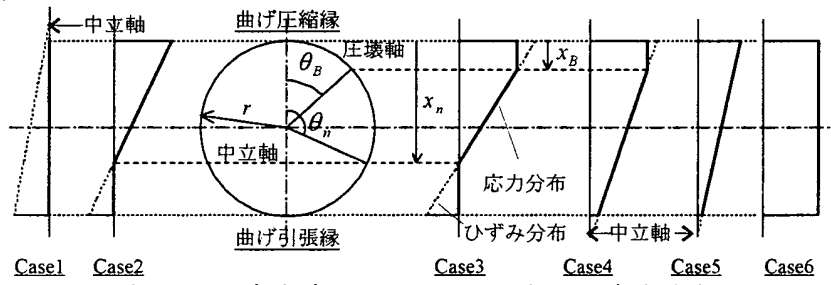

図 11 降伏時のコンクリート断面の応力分布 
Case1.中立軸が圧縮縁外にあるとき

$$
\left\{\begin{array}{l}
{ }_{c} N_{y}=0 \\
{ }_{c} M_{y}=0
\end{array}\right.
$$

Case2.中立軸が断面内にあり、压壊軸が存在しないとき

$$
\left\{\begin{array}{l}
\frac{{ }_{c} N_{y}}{2 \cdot{ }_{c} E \cdot r^{3} \cdot \phi}=\frac{\sin ^{3} \theta_{n}}{3}-\cos \theta_{n} \cdot\left(\frac{\theta_{n}}{2}-\frac{\sin 2 \theta_{n}}{4}\right) \\
\frac{{ }_{c} M_{y}}{2 \cdot{ }_{c} E \cdot r^{4} \cdot \phi}=\frac{1}{8}\left(\theta_{n}-\frac{\sin 4 \theta_{n}}{4}\right)-\cos \theta_{n} \cdot \frac{\sin ^{3} \theta_{n}}{3}
\end{array}\right.
$$

Case3.中立軸が断面内にあり、圧壊軸が存在するとき

$$
\left\{\begin{aligned}
\frac{{ }_{c} N_{y}}{2 \cdot{ }_{c} E \cdot r^{3} \cdot \phi}= & \frac{\sin ^{3} \theta_{n}}{3}-\cos \theta_{n} \cdot\left(\frac{\theta_{n}}{2}-\frac{\sin 2 \theta_{n}}{4}\right) \\
& -\frac{\sin ^{3} \theta_{B}}{3}+\cos \theta_{B} \cdot\left(\frac{\theta_{B}}{2}-\frac{\sin 2 \theta_{B}}{4}\right) \\
\frac{{ }_{c} M_{y}}{2 \cdot{ }_{c} E \cdot r^{4} \cdot \phi} & =\frac{1}{8}\left(\theta_{n}-\frac{\sin 4 \theta_{n}}{4}\right)-\cos \theta_{n} \cdot \frac{\sin ^{3} \theta_{n}}{3} \\
& -\frac{1}{8}\left(\theta_{B}-\frac{\sin 4 \theta_{B}}{4}\right)+\cos \theta_{B} \cdot \frac{\sin ^{3} \theta_{B}}{3}
\end{aligned}\right.
$$

Case4.中立軸が引張縁外にあり、圧壊軸が存在するとき

$$
\left\{\begin{aligned}
\frac{{ }_{c} N_{y}}{2 \cdot{ }_{c} E \cdot r^{3} \cdot \phi}= & \left(\frac{x_{n}}{r}-1\right) \cdot \frac{\pi}{2}-\frac{\sin ^{3} \theta_{B}}{3} \\
& +\cos \theta_{B} \cdot\left(\frac{\theta_{B}}{2}-\frac{\sin 2 \theta_{B}}{4}\right) \\
\frac{{ }_{c} M_{y}}{2 \cdot{ }_{c} E \cdot r^{4} \cdot \phi}= & \frac{1}{8}\left(\pi-\theta_{B}+\frac{\sin 4 \theta_{B}}{4}\right)+\cos \theta_{B} \cdot \frac{\sin ^{3} \theta_{B}}{3}
\end{aligned}\right.
$$

Case5.中立軸が引張縁外にあり、圧壊軸が存在しないとき

$$
\left\{\begin{array}{l}
{ }_{c} N_{y}=\pi \cdot r^{2}{ }_{c} E{ }_{c} \varepsilon_{0} \\
\frac{{ }_{c} M_{y}}{2 \cdot{ }_{c} E \cdot r^{4} \cdot \phi}=\frac{\pi}{8}
\end{array}\right.
$$

Case6.コンクリート全断面圧縮強度に至るとき

$$
\left\{\begin{array}{l}
{ }_{c} N_{y}=\pi \cdot{ }_{c} E \cdot r^{2} \cdot{ }_{c} \varepsilon_{B} \\
{ }_{c} M_{y}=0
\end{array}\right.
$$

（16） (21)式中で

$$
\begin{aligned}
& x_{n}=\frac{{ }^{c} \varepsilon_{0}}{\phi}+r \\
& x_{B}=x_{n}-\frac{{ }_{c} \varepsilon_{B}}{\phi} \\
& \cos \theta_{n}=1-\frac{x_{n}}{r} \\
& \cos \theta_{B}=1-\frac{x_{B}}{r}
\end{aligned}
$$

(12)式で鋼管の $M-N$ 相関曲線を描き、その各点に対応する $\approx$ と $\phi$ を(13) (15)式で求め(16) (21)式に代入して求められるコンクリー トの $M-N$ 相関曲線を累加すれば $M_{y}-N_{0}$ 相関曲線が求められる。

計算結果を実験値と重ねて図 12 (a)に示す。この計算方法による 降伏 $M-N$ 相関曲線は、文献8）によるものとほぼ等しく、実験值と の比較でも、同様に $D / t=45$ のとき、計算值が実験値を過小評価する が、 $D / t=72 、 D / t=103$ のきはよい一致を示す。

\section{終局耐力推定式}

終局耐力 $M_{u}$ は、鋼管の終局 $M-N$ 相関曲線、コンクリートの終局 $M-N$ 相関曲線を個別に求め、それらの一般化累加耐力とする。コ ンクリートの終局 $M-N$ 相関曲線は、文献8) の方法に準じて求める が、コンクリートを拘束する鋼管の周方向応力に関して、文献8）と は違う方法を用いる。図 9 の実験結果をもとに、降伏から終局に至 るまでの挙動に以下の仮定を設ける。

1) 鋼管の圧縮縁では、降伏応力に達した後、Misesの降伏曲線上を 周方向引張応力が増える方向に移動する。したがって軸方向圧縮 応力は減少する（図１０（a）参照）。Misesの降伏曲線上のどの位 置まで移動するかは、便宜上コンクリートに対する拘束力が径厚 比にかかわらず等しくなる位置とする。

2) 鋼管の引張縁では、降伏応力に達した後Misesの降伏曲線上を周 方向引張応力が増える方向に移動する。したがって軸方向引張応 力は増加する。終局耐力時には軸方向応力が最大になる点まで移 動する（図 10 (a)参照)。

3)鋼管の側面では、周方向忘力は生じない。

鋼管の終局 $M-N$ 相関曲線、及びコンクリートの終局 $M-N$ 相関 曲線は、下式による。

$$
\begin{aligned}
& \left\{\begin{array}{l}
{ }_{s} N_{u}={ }_{s} \sigma_{y} \cdot(D-t) \cdot t \cdot\left\{\beta_{1} \cdot \theta_{n}-\beta_{2} \cdot\left(\pi-\theta_{n}\right)\right\} \\
{ }_{s} M_{u}=\frac{1}{2} \cdot{ }_{s} \sigma_{y} \cdot(D-t)^{2} \cdot t \cdot\left(\beta_{1}+\beta_{2}\right) \cdot \sin \theta_{n}
\end{array}\right. \\
& \left\{\begin{array}{l}
{ }_{c} N_{u}={ }_{c} \sigma_{c B} \cdot r^{2} \cdot\left(\theta_{n}-\sin \theta_{n} \cdot \cos \theta_{n}\right) \\
{ }_{c} M_{u}=\frac{2}{3} \cdot{ }_{c} \sigma_{c B} \cdot r^{3} \cdot \sin ^{3} \theta_{n}
\end{array}\right.
\end{aligned}
$$

ここで、 $\beta_{1} 、 \beta_{2}$ は、周方向応力を考虑した、圧縮降伏、引張降伏の 修正係数で、下式で表わされる。 ${ }_{s} \sigma_{\theta}$ の添字 $(C)$ は圧縮縁、 $(T)$ は引 張縁、 $(S)$ は側面を意味する。

$$
\begin{gathered}
\beta_{1}=\frac{{ }_{s} \sigma_{\theta(C)} / s \sigma_{Y}+\sqrt{4-3 \cdot\left({ }_{s} \sigma_{\theta(C)} / s_{s} \sigma_{Y}\right)^{2}}}{2} \cdots \ldots . . . \\
\beta_{2}=\frac{-{ }_{s} \sigma_{\theta(T)} /{ }_{s} \sigma_{Y}+\sqrt{4-3 \cdot\left({ }_{s} \sigma_{\theta(T)} / s \sigma_{Y}\right)^{2}}}{2} \\
\text { コンクリートの横方向拘束応力度は、 }
\end{gathered}
$$

$$
\sigma_{H}=-\sigma_{\theta} \cdot \frac{t}{r}
$$

で表されるから、仮定1）により鋼管の圧縮縁の周方向応力度は $t / r k$ 反比例する。すなおち、

$$
\sigma_{\theta(C)}=-a \cdot \frac{r}{t}
$$

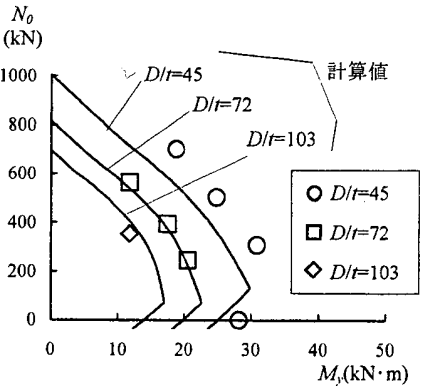

(a) 降伏耐力

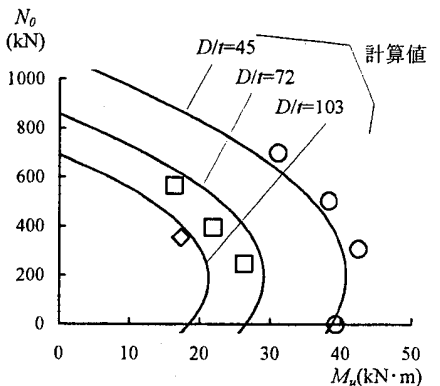

(b) 終局耐力
図１２プレストレス量と降伏耐力、終局耐力の関係 (提案式との比較) 
ここで、

$$
a: \text { 比例定数 }
$$

したがって、

$$
\beta_{1}=\frac{-\frac{a}{{ }_{s} \sigma_{Y}} \cdot \frac{r}{t}+\sqrt{4-3 \cdot\left(\frac{a}{{ }_{s} \sigma_{Y}} \cdot \frac{r}{t}\right)^{2}}}{2}
$$

引張縁の周方向応力度は、仮定2)より、

$$
{ }_{s} \sigma_{\theta(T)}=-\frac{1}{\sqrt{3}} \cdot{ }_{s} \sigma_{Y}
$$

したがって、

$$
\beta_{2}=\frac{2}{\sqrt{3}}
$$

仮定3)より側面の周方向応力度は、

$$
{ }_{s} \sigma_{\theta(s)}=0
$$

周方向応力は、終局状態において鋼管の全周にわたって一定では ないため、コンクリートの拘束力として全周の平均值を用いる。な お、鋼管の側面では周方向応力度を0とする仮定のため、側面では 軸方向降伏応力度が $\beta_{1} \sigma_{\mathrm{y}}$ や $\beta_{2} \sigma_{\mathrm{y}}$ にはならないが、両側面の 90 度範囲

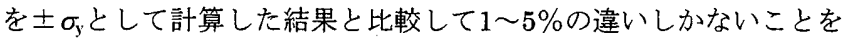
確認し、簡単のため、(26)、(27)式は側面でも $\beta_{1} \sigma_{y}$ や $\beta_{2} \sigma_{y}$ となる式と した。

$$
\sigma_{\theta}=\frac{\sigma_{\theta(\mathcal{C})}+\sigma_{\theta(T)}+2 \cdot \sigma_{\theta(S)}}{4}
$$

なお、文献8)では、 $\sigma_{\theta}=-0.19_{s} \sigma_{Y}$ (一定値) としている。 ここでは、拘束コンクリートの強度として下式10)を用いる。

${ }_{c} \sigma_{c B}= \begin{cases}{ }_{c} \sigma_{B} \cdot\left(1+5.0 \cdot \frac{\sigma_{H}}{{ }_{c} \sigma_{B}}\right) & \ldots\left(\frac{\sigma_{H}}{{ }_{c} \sigma_{B}} \leq 0.05\right) \\ { }_{c} \sigma_{B} \cdot\left(1.125+2.5 \cdot \frac{\sigma_{H}}{{ }_{c} \sigma_{B}}\right) & \ldots\left(\frac{\sigma_{H}}{{ }_{c} \sigma_{B}}>0.05\right)\end{cases}$

(26) 式と (27) 式を累加することにより本構造断面の終局 $M-N$ 相関 曲線が求められる。比例定数 $a$ は、実験結果を平均的によく評価で きるように選ぶものとする。(31) 式の比例定数 $a$ を 5.0 とし、実験值 と計算值を重ねて図 12 (b)に示す。 $D / t=45 、 D / t=72 、 D / t=103$ のと きすべてにおいて実験結果と比較的良い一致を示す。

\section{5. 結論}

コンクリート部分のみにプレストレスを導入したコンクリート充 填円形鋼管部材を対象に鋼管の径厚比、プレストレス量を変化させ た8体の試験体を用いて一方向載荷の曲げ実験を行った。その結果 以下の結論が得られた。

1）プレストレスを導入した7体は、鋼管に局部座屈は生じるものの 荷重低下はなく、実験を終了した $R=150 \times 10^{-3} \mathrm{rad}$ まで単調に荷重 が上昇するきわめて勒性に富んだ性状を示した。

2) 本実験の範囲では、プレストレス量 $N_{0}$ が $N_{u}$ の0.3倍のときに降伏耐 力が最大となる。

3）初期曲げ岡性は、鋼管とコンクリートの平面保持、コンクリート の応力状態をPS量によって弾性状態や、断面の一部が引張に なったり、コンクリート強度に達したりして非弾性になる場合 があることを仮定した計算により評価できる。
4) 降伏耐力と終局耐力を文献8)で評価した結果、降伏耐力は、 $D / t$ =72、103ではほぼ一致した。 $D / t=45$ では、やや過小評価となっ

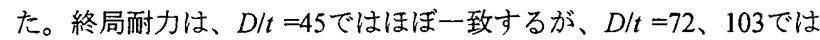
過大評価となった。

5）鋼管とコンクリートの間に軸方向ひずみ差が生じることを考慮 し、コンクリートの忘カーひずみ関倸を完全弹塑性型と仮定し た方法で降伏曲げ耐力の推定式を提案した。また、鋼管のコン クリートに対する拘束応力度を仮定し、コンクリートの強度上 抙を文献10)に従って計算し、銅管との単純累加による終局耐力 の推定式を提案した。

6）降伏耐力と終局耐力の提案推定式は、降伏耐力については文献8) とほぼ同等の評価を与えた。終局耐力については、文献8)より実 験結果に近い評価を与えた。

径厚比が小さいときの降伏耐力の推定式の精度改善、終局耐力推 定式のための鋼管によるコンクリートの拘束応力度の一般化、繰返 し加力の場合の曲げ性状は今後検討すべき課題である。

\section{謝辞}

本研究を行うにあたって、佐伯俊夫氏（元 鹿島技術研究所 副所 長）のご指導を仰ぎました。ここに記して謝意を表わします。

\section{参考文献}

1）前川幸次、梶川康男、吉田博：PC鋼棒で補強されたコンクリート充填鋼管 はりの曲げ耐荷力に関する研究、構造工学論文集、Vol.39A、pp153·164、 1999.3

2) 小林将志、石橋忠良、菅野貴浩、三幣高吉 : プレストレスト銅管コンク リートの耐荷力試験、コンクリート工学年次論文報告集、Vol.17、No2、 pp737-742、1995

3）小林 将志、三幣 高吉、石橋 忠良: プレストレスを与えたコンクリート充 填鎆管梁の曲げ耐力に関する研究、土木学会関東支部、pp514-515、1995

4) 小林将志、川崎徹、米倉賴夫 : プレストレスト銅管コンクリートの曲げ耐 荷力試験、土木学会大会、pp864-865、1995.9

5) 大久保啓一、山内俊幸、堀江雅直 : プレストレスを与えたコンクリート充 填鋼管ばりの変形特性、土木学会関東支部、pp516-517、1995

6) 大久保啓一、山内俊幸 : プレストレスを与えたコンクリート充填鋼管梁の 変形特性、土木学会大会、pp860-861、1995

7) 保坂鉄矢、堀地紀行、西海健二、依田照彦: コンクリート充填鋼管桁のPC 鋼線による補強効果汇関する実験、士木学会大会、pp372-373、1999.09 8) 日本建筑学会：鉄骨鉄筋コンクリート構造計算規準・同解説、2001.1 9)山田嘉昭：マトリックス法材料力学、培風館、1971.4 10)CEB-FIP model code 1990 Final draft Chapters1-3、1991 